\section{Report on the Third Session of the \\ Intergovernmental Soviet-Canadian Mixed Commission on \\ Economic, Industrial, Scientific and Technical Cooperation \\ Moscow, June 2-3, 1983}

On June $2-3,1983,1$ was a member of the Canadian delegation to the Third Session of the Intergovernmental SovietCanadian Mixed Commission on Economic, Industrial, Scientific and Technical Cooperation held in Moscow, USSR. This meeting was the first meeting held since 1978; it had been delayed since 1979.

The Canadian delegation for the Mixed Commission meeting was headed by the Hon. Gerald Regan, Minister of State (International Trade). The delegation consisted of officials of External Affairs, the Export Development Corporation and Department of National Revenue (Customs Programs Branch), five representatives from Working Groups and nine business representatives primarily from gas and oil and agricultural equipment firms. The Soviet delegation was headed by the Deputy Minister of Foreign Trade, V.N. Sushkov.

The formal meetings consisted of three plenary sessions, two held on June 2 nd and one on June 3rd. Mr. Sushkov served as chairman. The first session was devoted to opening remarks by Mr. Sushkov and Mr. Regan. These statements were highlighted by general comments on current economic conditions in each country and a review of the current trade situation between the two countries. Presently, Canadian exports to the USSR slightly exceed $\$ 2$ billion of which $94 \%$ are sales of grain. Other important exports include a wide variety of goods including sulfur, metal ores and concentrates, chemical products, special industry machinery and motor vehicles and products. These non-grain exports totalled $\$ 122.6$ million in 1982. USSR exports to Canada totalled $\$ 42.9$ million in 1982 . USSR exports to Canada are dominated by motor vehicles and parts, particularly the Lada car and the Soviets are concerned with lower sales of the car in 1982, attributed to our economic situation. In view of this trade imbalance, it is not surprising that the Soviets are extremely anxious to increase their Canadian exports; at the same time Canada is anxious to increase its trade in non-grain products, particularly oil and gas and agricultural equipment which are seen as two key areas. It is important to note that the USSR is now the 4th largest Canadian export market.

The second plenary session was devoted to a review of Working Group activities under the Mixed Commission. C. Charland, ADM, Trade Development, External Affairs, outlined activities on behalf of Canada and Mr. Inozemitrev, USSR State Planning Committee for the USSR. In particular, activities of the electric power, oil and gas, architecture, geol- ogy, transportation and forestry working groups were reviewed. It is evident that working group activities have varied substantially over recent years; the Sovietside wishes to increase working group activity. Both sides placed emphasis on commercial activities within the Working Groups.

The third plenary session was devoted to the presentation of brief statements by most of the Canadian business representatives. They outlined their organization and their current relationships and involvements in the Soviet Union. The session also included a statement from a representative of the USSR firm. Machineryimport. Again interest was expressed with respect to oil and gas equipment, but the speaker again noted the need for increased Soviet imports to Canada.

The formal meeting concluded with the signing of the protocol and a decision to hold the fourth Meeting of the Mixed Commission in Canada, the second half of 1984. Details concerning location and timing are to be concluded by officials of the two governments.

While in Moscow. Canadian Working Group and business representatives met with Soviet counterparts. On May 31, I met with the Soviet Chairman of the Forestry Working Group, Mr. P.I. Moroz. Our meeting reviewed the current exchange program 1981-83, the Canadian tree improvement delegation to the USSR in 1983 and the Third Meeting of the Working Group which is planned for Canada in October, 1983. A separate report discusses this meeting. On May 31, I attended a meeting with officials of the State Committee for Science and Technology, basically to discuss the role of this committee in international relationships.

J.H. Cayford

\section{Première réunion du Comité consultatif de la recherche sur la forêt et les produits forestiers}

Le ${ }^{\text {er }}$ juin dernier, avait lieu au Château Bonne Entente à Québec, la première réunion du Comité consultatif de la recherche sur la forêt et les produits forestiers. Ce Comité a pour but de favoriser la meilleure utilisation possible des ressources disponibles au Ministère de l'Energie et des Ressources dans le domaine de la recherche et du développement expérimental et de bien répondre aux besoins de $R / D$ dans le secteur forestier au Québec, en tenant compte des travaux qui se font dans les autres organismes.

Cette première rencontre a semblé grandement satisfaire les participants. La journée a été consacrée à l'organisation de la recherche au M.E.R. et à la présentation des différentes sphères et domaines qui font actuellement l'objet de travaux de recherche; les participants ont également formulé certaines recommandations.

\section{Recommandations}

Ces dernières sont allées dans le sens d'une plus large consultation et d'une meilleure coordination de la recherche et ceci à tous les niveaux. On souhaite également que le M.E.R. intensifie ses efforts de R/D dans les domaines de l'amélioration et la protection de la forêt ainsi que de la connaissance écologique et dendrométrique de la forêt; également, qu'il se concentre davantage sur un plus petit nombre de projets bien définis et dont l'impact est significatif.

Au niveau de l'organisation et de l'exécution de la recherche, on souhaite que le M.E.R. augmente ses ressources à ce chapitre compte tenu de l'importance de la forêt dans l'économie du Québec.

De plus, les participants ont tous reconnu l'importance de diffuser les résultats de recherche, de les publiciser, de les vulgariser et d'en faire un véritable marketing auprès des praticiens. Un bilan de ces recommandations sera fait lors de la prochaine réunion du Comité.

\section{Le Fonctionnement du Comité}

Le Comité doit se réunir une fois par année; cette rencontre a pour but d'informer les participants des programmes du Ministère en matière de recherche et développement concernant la forêt et les produits forestiers; de conseiller le M.E.R. sur les travaux en cours et ceux qui devraient être entrepris ainsi que les moyens de les réaliser.

Convoqué par le directeur de la Planification du M.E.R., le Comité consultatif est formé de six représentants de l'entreprise privée ainsi que d'un représentant de Rexfor, de la Fédération des producteurs de bois du Québec, du Centre de recherche forestière des Laurentides et de la Faculté de foresterie et de géodésie de l'Université Laval. Le M.E.R. est représenté pour sa part par les directeurs de ses principales directions générales. 